\title{
DESIGN OF FUEL'S VOLUME MEASUREMENT MONITORING SYSTEM ON INDONESIAN NAVY FUEL TANK "SPBT" BASED ON THE Internet of Things (IOT)
}

\author{
Mochammad Faturrochman, Suprayitno, M. Zulkifli, Edy Widodo \\ D-3 Informatics Engineering, Indonesian Naval Technology College \\ www.sttal.ac.id
}

\begin{abstract}
Refueling Stations are places where motorized vehicles can get fuel. The Refueling Station in the TNI is known as the SPBT (TNI Refueling Station) or often referred to as the gas station. SPBT generally only provides two types of fuel such as Premium (MT88) and diesel (HSD). This SPBT usually has a tank that is used to hold fuel oil which will later be used for Dinas vehicles. The development of science, technology creation at this time has penetrated digital technology. Most of the technology used by humans is completely digital. In this case it is very helpful in various aspects, for example in the industrial sector, many industrial fields have used digital technology due to human limitations and are demanded to be fast, practical and precise. Of the several applications of digital technology, one that is needed in an industrial field is a tool to monitor a material that is in a closed container. This technology helps officials to monitor the amount of fuel from the field without having to open the material container when they want to find out information about the fuel. As one example is the technology to monitor the condition of fuel oil storage tanks in the SPBT within the Navy to find out information on the volume of fuel in the tank.
\end{abstract}

Keywords: Kodiklatal SPBT, Internet Of Things (IOT) Fuel Volume Monitoring System.

\section{Introduction}

Refueling Stations are places where motorized vehicles can get fuel. The Refueling Station in the TNI is known as the SPBT (TNI Refueling Station). SPBT generally only provides two types of fuel such as gasoline (MT88) and diesel (HSD). This SPBT usually has a tank that is used to hold fuel oil which will later be used for Dinas vehicles.

The development of science, technology creation at this time has penetrated digital technology. Most of the technology used by humans is completely digital. In this case it is very helpful in various aspects, for example in the industrial sector, many industrial fields have used digital technology due to human limitations and are demanded to be fast, practical and precise. Of the several applications of digital technology, one that is needed in an industrial field is a tool to monitor a material that is in a closed container. This technology helps the officers to monitor a material from the field without having to open the material container when they want to find out information about the material. As one example is the technology to monitor the condition of fuel oil pile tanks in
SPBT in the Navy to find out information on the volume of fuel in the tank.

Measurement of fuel oil buried tank is still using lagsung measurement which is measured manually by using a tool that is a measuring stick commonly called Deepstick. It also can use water paste and oil paste to help read the height limit when measuring, but there are also those who use chalk in addition to water and oil paste. Manual measurement has several disadvantages including when measurements are made at night with inadequate lighting conditions, the measurement becomes inaccurate.

It is necessary to check the baton to ensure that the stick used is not bent when inserting the long stick into the tank must be slow because there is no surge on the surface of the fuel. In addition, long sticks that are not directed perpendicular to the center of the burial tank will cause inaccurate measurement results. To overcome this, a fuel storage tank monitoring system is needed on the Navy's SPBT digital, so you can easily and easily identify real oil stocks. Referring to technological developments, use of the internet as if it would be mandatory because it is practical and fast. Therefore, to display data 
on the results of monitoring temperature depth and volume of fuel in the tank, Internet of Things (loT) technology is used. The technology is one of the current technological developments. The development of a monitoring system for monitoring the measurement of fuel oil in the underground tanks in the loT-based SPBT Navy is expected to be able to assist SPBT officers / members in monitoring or checking fuel storage tanks in SPBT practically, quickly and accurately. Expected to no longer check the burial tank with a long stick manually. They only need to see the measurement data through electronic devices that can be connected to the internet. In addition, it will also be known when the right time to replenish fuel stock before it runs out.

\section{Research Methods}

\subsection{Conceptual Framework}

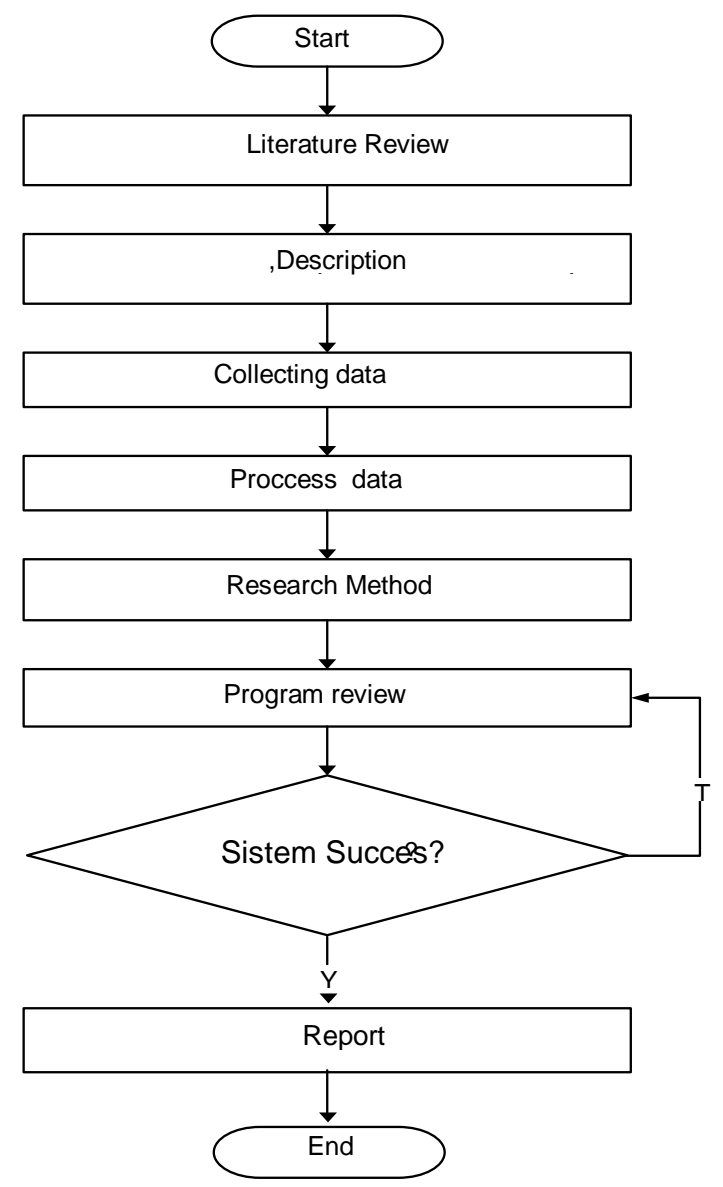

Figure 1: Overall Research Flowchart

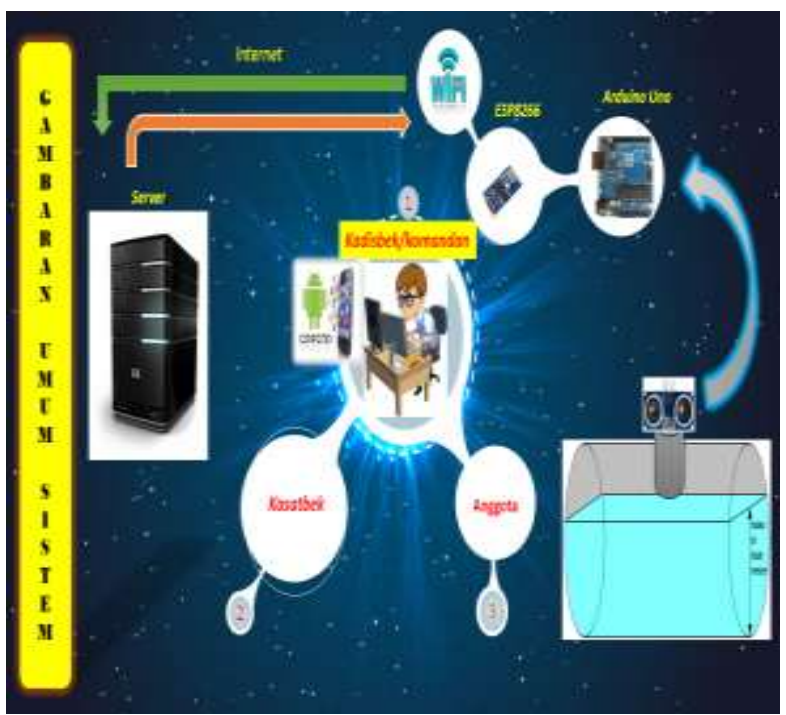

Figure 2: Overview

\subsection{Research Design}

This system has several needs that must be achieved in order to be perfect and in accordance with the objectives to be achieved. The basic needs that must be met to design a system are as follows:

\section{a. System Flowchart Process Monitoring.}

The fuel monitoring process in the tank can be illustrated in Figure 3, the need for a sensor as an input to detect how much oil is monitored in the tank, the detection results from the sensor are processed by a microcontroller and uploaded to the ESP8266 wifi module, the reading data is stored in the My Sql database to later be displayed on the My Sql database to later be displayed on web browser that is accessed by users from both PC and Smartphone. 


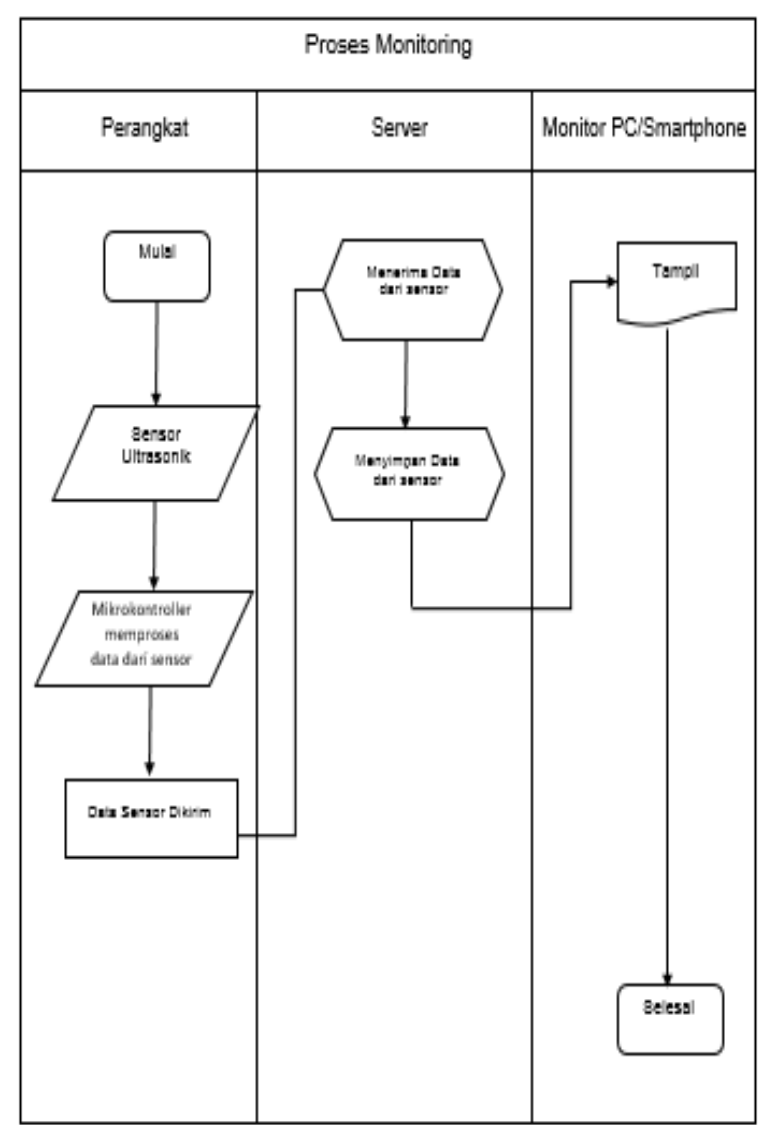

Figure 3: Gas Flow Monitoring System Flow System

b. Entity Relationship Diagram (ERD) Entity Relationship Diagrams (ERD) are developed using tables that are made according to need.

1) Database

Physical Data Model The monitoring system of BBM volume measurement in the Indonesian Navy shows that there are several database tables in the system. The following is a database design for the monitoring system of BBM volume measurement in the Navy.
Table 1: Member data

\begin{tabular}{|c|c|c|c|}
\hline Nama Field & Tipe Data & Size & Keterangan \\
\hline id & integer & 3 & Primary key \\
\hline Nama & Varchar & 20 & \\
\hline pangkat & Varchar & 10 & \\
\hline korps & Varchar & 10 & \\
\hline nrp & Varchar & 10 & \\
\hline kotama & Date & 10 & \\
\hline hp & Varchar & 15 & \\
\hline alamat & Varchar & 100 & \\
\hline
\end{tabular}

Table 2: Table and data member

\begin{tabular}{|c|c|c|c|}
\hline Nama Field & Tipe Data & Size & Keterangan \\
\hline nrp & integer & 10 & Primary key \\
\hline nama & Varchar & 30 & \\
\hline pangkat & Varchar & 10 & \\
\hline korps & Varchar & 10 & \\
\hline jabatan & Varchar & 50 & \\
\hline userid & Date & 20 & \\
\hline password & Varchar & 40 & \\
\hline level & Varchar & 11 & \\
\hline
\end{tabular}




\section{Results}

Research on the design of the Internet of Things (loT) for the fuel monitoring system on the storage tank is done by testing the overall system. The results were obtained based on tests conducted on measurements through ultrasonic sensors by reading the distance at the level of fuel volume that is in the tank. The test results concluded that to find out the amount of fuel volume available, the sensor captures the distance of the existing volume in the tank so as to get the amount of fuel volume. The following is the percentage of sensor distance and percentage of fuel volume, which can be seen in table 1 and table 2

Table 3: Sensor Testing

\begin{tabular}{|c|c|c|c|}
\hline No & $\begin{array}{c}\text { Jarak sebenarnya } \\
(\mathrm{cm})\end{array}$ & $\begin{array}{c}\text { Jarak terbaca sensor } \\
(\mathrm{cm})\end{array}$ & \%Error \\
\hline 1 & 20 & 21,84 & $0,4 \%$ \\
\hline 2 & 16 & 16,73 & $0,4 \%$ \\
\hline 3 & 11 & 11,62 & $0,5 \%$ \\
\hline 4 & 6 & 6,51 & $0,8 \%$ \\
\hline
\end{tabular}

Tabel 4: Pembacaan Volume

\begin{tabular}{|c|c|c|c|}
\hline No & $\begin{array}{c}\text { Volume Sebenarnya } \\
\text { (Liter) }\end{array}$ & $\begin{array}{c}\text { Volume perhitungan } \\
\text { (Liter) }\end{array}$ & \%Error \\
\hline 1 & 5 & 5,11 & $1 \%$ \\
\hline 2 & 10 & 10,22 & $1 \%$ \\
\hline 3 & 15 & 15,33 & $1 \%$ \\
\hline 4 & 20 & 20,45 & $1 \%$ \\
\hline
\end{tabular}

\section{Discussion}

Research on the design of the Internet of Things (IOT) for the fuel monitoring system on the storage tank is a type of applied research, because this research aims to provide solutions and focus more on the application of duty in daily life. This research can help the task of members of the spbt in carrying out checking or measuring the volume of the tank more easily and there are no difficulties in the task, so as to obtain accurate results and realtime data. This study also uses engineering methods because this research applies science into an effective and efficient system design.

This research was conducted based on the needs of the organization, especially in filling the Kododatal Surabaya surabaya fuel unit to facilitate when carrying out the task as a member of the spbt. With this system, the parties can easily find out and monitor how much fuel stock is available at that time. In addition, there is also no cheating in distribution, especially in Surabaya Kodiklatal Surabaya.

\section{Conclusions}

Based on the results of the tests that have been carried out on the design of the Monitoring System of Fuel Volume Measurement on an Internet of Things (IOT) based Stockpile Tank at the Kodiklatal SPBT, the following conclusions can be obtained:

a. Can input, edit, and delete and display real-time BBM volume data at the Surabaya Kodiklatal SPBT.

b. Can display daily report data in realtime

c. Can monitor at any time the final amount of fuel volume in the SPBT tank without having to measure it again manually.

d. Can store BBM data, so you can search for BBM data from start to finish

e. Can print BBM data as a source to support daily reporting.

\section{References}

Jogiyanto, H. (2005). Analysis and design of information systems. Yogyakarta.

Kadir, A. (2003). Introduction of information systems. Yogyakarta. 
M, E. W. (2012). Water tendon control and monitoring tools using Avr and ultrasonic microcontrollers. Surabaya.

Putra, V. Z. (2011). Design of Gas Height Measurement Measuring Instrument in Gas Station Reservoir with Ultrasonic Sensor. Padang.

Ulfah, Arief Mediaty. (2015). Sensor Testing for Ultrasonic Measurement of Water level and Water Volume. Journal of Electrical Engineering.

Yuda, K. (2010). Implementation of Ultrasonic Level Detectors in the Monitoring Tank of the Embedded Tank at the gas station. Surabaya.

Kiswanto, H., Prasetyo, S., Suprayitno, S., \& Marbandi, A. (2017). Sistem Informasi Rumah Negara Di Lantamal. International Journal Of ASRO - STTAL, 7, 1-8. Retrieved from http://asrojournalsttal.ac.id/index.php/ASRO/article/view/ $\underline{222}$

Minarto, M., Majid, A., Ahmadi, A., \& Bukit, A. (2017). Rancang Bangun Aplikasi Sistem Pencatat Keluar Masuk Personel Di Penjagaan Sttal Surabaya Berbasis Rfid. International Journal Of ASRO STTAL, 8, 1-16. Retrieved from http://asrojournal-

sttal.ac.id/index.php/ASRO/article/view/ $\underline{223}$

Jaya, I., Maryanto, E., Bukit, A., \& Zulkifli, M. (2018). Design And Development Of Early Heat Stroke Detection System In Military Cross Country Based On lot. International Journal Of ASRO - STTAL, 9(2), 141-151. Retrieved from http://asrojournal-

sttal.ac.id/index.php/ASRO/article/view/ $\underline{230}$

Sulistyono, E., Mahia, F., Bandono, A., \& Syahlan, Z. (2018). Design And Manufacture Of Indonesian Naval Warship Technical Condition Report And Inventory Information System. International Journal OF ASRO STTAL, 9(2), 133-140. Retrieved from http://asrojournal-
sttal.ac.id/index.php/ASRO/article/view/ 229

Purwito, A., Sitanggang, D., Suprayitno, S., \& Marbandi, A. (2018). Design Of Prison Security Information System Using Rfid. International Journal OF ASRO STTAL, 9(1), 129-135. Retrieved from http://asrojournal-

sttal.ac.id/index.php/ASRO/article/view/ 227 